\title{
Experimental Studies on the Infulences of Androgenic Agents upon the Seminal Vesicles of Castrated Rat
}

By

Sadamu DOHI

Department of Obstetrics and Gynecology, Kyoto Prefectural Medical College

(Director ; Prof. Dr. G. Sawasaki, M.D.)

By seminal vesicle and prostata weighing test (Fevold) was performed, and the results were as follows : Testosterone suspension and oil solution had short acting effects, and in 5 days after administration, it showed the maximum effects, but durated no longer.

On the contrally, testosterone $\beta$-cyclopentyl propionate had no short acting effects. But its effects were strong and maximum effects were 2 times or more greater than that of testosterone or testosterone propionate and durated for 1 month or more after the administration.

\section{Co-operative Effects of Androgen and Estrogen \\ By}

\section{Sadamu DOHI}

Department of Obsterics and Gynecology, Kyoto Prefectural Medical College

(Director : Prof. Dr. G. Sawasaki, M.D.)

(1) By means of seminal vesicles and prostata weighing test (Fevold), we investigated the co-operative functions of androgen and estrogen mixture agents day by day.

By changing their ratio and dosis, some interesting results were obtained.

Maximum co-operative effects were observed under following conditions :

i.e. By $5 \mathrm{mg}$. and $2.5 \mathrm{mg}$, testosterone to estrogen ratio was 30 to 1 .

By $1.25 \mathrm{mg}$, the ratio was 20 to 1 .

(2) According to the rise of estrogen level, the peak of maximum effects shifted to the right and aslo became uneffective.

As above mentioned, when the androgenic effects were wanted in administration of mixture hormone, estrogen ratio to androgen might not be too great.

\section{On the Estrogen and Progesterone Secreting Cells of the Human Placenta By}

\section{Keishi MATSUMOTO}

IInd Department of Pathology, Osaka University (Director : Prof. Dr. T. Yasuda)

The chemical assay of urine pregnanediol, estriol, estradiol and estrone of 25 pregnant women 3 to 5 days before parturition, 8 women of 7 months pregnancy, 5 women of 6 months pregnancy and 5 


\title{
Androgen 及で Ëstrogen の協力作用について
}

\author{
京都府立医科大学産婦人科学教室（主任 沢崎千秋教授） \\ 研究生土肥定
}

\section{第 1 章 いとぐち}

内分泌学の進歩により Androgen についての研究屯過去に於ける睪丸と睪丸ホルモンのみを研究すればよ い時代はすぎ去り，過去の情ホルモンが幽特異的であるとの観念から完全に脱し，男女性共に両幽のホルモ ンが分泌され，両性ホルモンが共に不可欠な生理作用を営むむのであるという性ホルモンの性非特異的観念 によりその作用及び代謝か観察される様になつた。

従つて男性ホルモンと女性ホルモンとの関係については近年その相関作用の研究が盛んになり，それを利 用しての混合ホルモン療法が盛んになつて来たが，その両ホルモンの混合比を種々に变化するてとによりそ の作用が変化するが，ての混合比の問題は未だ確定していない．てれは最近混合ホルモンが盛んに利用され る様になつた理由の一つとして，その協力作用を期待する以外唡性のホルモンの各々の特性を利用するて とにより, Androgen 及び Estrogen 各々の治療効果を期待し, その各々の副作用をお互に防止させようと する観点から利用されている為である。

そのため混合比の問題も主に臨床的方面からのみその優劣が論ぜられ，混合ホルモンの協力作用について は未だ充分なる考察がなされていない為ではないかと考学られる。

私は去勢ラッテ精襄前立腺試験1) により混合ホルモンの協力作用についてその混合比，投与量及び投与後 の経過による変動を観察し，その最大協力作用を発揮する混合比及び投与量についていささかの知見を得た ので此処に報告する.

\section{第 2 章 Androgen と Estrngen の協力作用}

\section{第1笻 実験方法と材料}

実験材料としては生後30日～40日目の体重 40～50g の純系ラッテを使椆，一定期間完全飼料で恒温恒湿の 下に飼育観察後去勢し, 去勢後 20 日目に1.25mg, $2.5 \mathrm{mg}, 5 \mathrm{mg}$ の Testosterone (以下T.と略)，Estradiol benzoate（以下E.と略）の混合ホルモン剂を投与しその混合比を種々に変化して観察した. 投与方法は脊部 皮下注射とし，注射街所定日数を経て屠殺し，精袈，前立腺を科量するてとによつてそのホルモン作用を比 輍した。精囊の剔出に当つては精液の流出に注意し, 剔出後 Bouin 氏液 $2 \sim 3$ 日間固定後 $70 \%$ アルコール にて洗い，精囊，前立腺を分離科量した。

\section{第 2 節 実 験 成 綪}

第 1 表は各投与量及び混合比を变化するととによつて得た個々の体重 $100 \mathrm{~g}$ 換算平均值を示している，投与

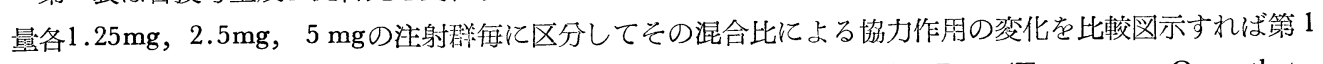
図, 節 2 図, 第 3 図の如くになる。文混合ホルモンデボ剤である Primodian Dteot(Testosterone Oenanthate: Estradiol ValerianaT $=.6 .25: 1$ ) と Testosterone- $\beta$ Cyclopentylpropionate (T.CP.と略)各 $5 \mathrm{mg}$ 投与成績を 比較図示すれば第4 図の如くになる。

以上の成績を見るに1.25mg投与群では，Testosterone : Estradiol (以下 $\mathrm{T}: \mathrm{E}$ と略) $=20: 1,2.5 \mathrm{mg}, 5 \mathrm{mg}$ 投与群では $\mathrm{T}: \mathrm{E}=30: 1$ の混合比に於いて, 又 $1.25 \mathrm{mg}, 2.5 \mathrm{mg}$ 投与群では何れも投与後 10 日目に $5 \mathrm{mg}$ 投 与群では投与後15日目に於いて最大協力作用が認められた。

これに反し，混合ホルモンデポ剤に於いては T.C.P. に比しその協力作用は認められなかつた。 


\section{第3 章 考按}

Androgen に少量の Esrogen を混合するてとによつて Androgen 作用の增強が見られるととは，1940年 Korenchevsky2)が Androsterone, Androstendiol, 及びT.とE.との同時注射により腎重量は Androgen 単独 投与の場合と同様に，或いはそれ以上に肥大するととを見，副性器に対しても Castillo \& Pinto ${ }^{3)}$, Korenchersky) は Androgen に少量の Estrogen を混和投与すると前立腺の増大が Androgen 単独投与の場合よ りも増すととを認めている。然しながらこの協力作用は同時に投与する Estrogen の絶対量が Androgen に

第 1 表 Androgen 及び Estrogen の協力作用（去勢ラッテ精襄，前立腺試験による）

\begin{tabular}{|c|c|c|c|c|c|c|c|c|c|c|c|c|c|c|c|}
\hline \multirow[b]{2}{*}{$\begin{array}{l}\text { 投 } \\
\text { 与 } \\
\text { 量 } \\
\end{array}$} & \multirow{2}{*}{\begin{tabular}{|c|c|} 
投 与 後 日 数 \\
副性器重量 \\
$(\mathrm{mg})$
\end{tabular}} & \multicolumn{2}{|c|}{ 正常值 } & \multicolumn{2}{|c|}{$\begin{array}{l}\text { 去勢後 } \\
20 \text { 日目 }\end{array}$} & \multicolumn{2}{|c|}{$\begin{array}{l}\text { 投与後 } \\
3 \text { 日目 }\end{array}$} & \multicolumn{2}{|c|}{5 日 目 } & \multicolumn{2}{|c|}{10 日目 } & \multicolumn{2}{|c|}{15 日目 } & \multicolumn{2}{|c|}{ 20日目 } \\
\hline & & $\begin{array}{l}\text { 精 } \\
\text { 囊 } \\
\end{array}$ & $\begin{array}{l}\text { 前 } \\
\text { 立 } \\
\text { 腺 }\end{array}$ & \begin{tabular}{l|} 
精 \\
囊 \\
\end{tabular} & $\begin{array}{l}\text { 前 } \\
\text { 立 } \\
\text { 腺 }\end{array}$ & $\begin{array}{l}\text { 精 } \\
\text { 露 } \\
\end{array}$ & $\begin{array}{l}\text { 前 } \\
\text { 立 } \\
\text { 腺 } \\
\end{array}$ & $\begin{array}{l}\text { 精 } \\
\text { 囊 } \\
\end{array}$ & $\begin{array}{l}\text { 前 } \\
\text { 立 } \\
\text { 腺 } \\
\end{array}$ & 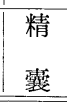 & \begin{tabular}{|l|} 
前 \\
立 \\
腺 \\
\end{tabular} & \begin{tabular}{l|} 
精 \\
囊 \\
\end{tabular} & $\begin{array}{l}\text { 前 } \\
\text { 立 } \\
\text { 腺 }\end{array}$ & $\begin{array}{l}\text { 精 } \\
\text { 霅 }\end{array}$ & $\begin{array}{l}\text { 前 } \\
\text { 立 } \\
\text { 腺 }\end{array}$ \\
\hline & $\begin{array}{l}\text { 正 常 值 (対照) } \\
\text { 去枩後20日目 (対照) }\end{array}$ & 28.3 & & 13.8 & 32 & & & & & & & & & & \\
\hline $\begin{array}{c}5 \\
\mathrm{mg}\end{array}$ & $\begin{array}{l}\mathrm{T} \cdot \text { 単独投与（対照） } \\
\mathrm{T}: \mathrm{E}=20: 1 \\
\mathrm{~T}: \mathrm{E}=30: 1 \\
\mathrm{~T}: \mathrm{E}=40: 1\end{array}$ & & & & & $\begin{array}{l}59.6 \\
76.9 \\
50.8 \\
56.4\end{array}$ & $\begin{array}{l}121.9 \\
189.2 \\
161.1 \\
149.8\end{array}$ & \begin{tabular}{|l|}
115.7 \\
103.6 \\
155.4 \\
110.1
\end{tabular} & $\left|\frac{6}{204.7}\right| \begin{array}{l}209.4 \\
230.3 \\
250.8\end{array} \mid$ & $\begin{array}{r}94.3 \\
28.7 \\
331.9 \\
120\end{array}$ & $\begin{array}{r}209.6 \\
88.0 \\
336.2 \\
274.6 \\
\end{array}$ & $\begin{array}{r}34.0 \\
16.3 \\
460.4 \\
57.8\end{array}$ & $\mid \begin{array}{r}11.0 \\
61.2 \\
360.6 \\
107.9\end{array}$ & $\mid \begin{array}{l}34.4 \\
13.9 \\
31.0 \\
31.8\end{array}$ & $\begin{array}{l}78.0 \\
41.3 \\
91.9 \\
75.4\end{array}$ \\
\hline $\begin{array}{l}2.5 \\
\mathrm{mg}\end{array}$ & $\begin{array}{l}\mathrm{T} \cdot \text { 単独投与（対照） } \\
\mathrm{T}: \mathrm{E}=20: 1 \\
\mathrm{E}: \mathrm{E}=30: 1 \\
\mathrm{~T}: \mathrm{E}=40: 1\end{array}$ & & & & & $\begin{array}{l}58.7 \\
54.8 \\
59.6 \\
63.1\end{array}$ & $\begin{array}{l}122.3 \\
113.6 \\
134.8 \\
146.3\end{array}$ & $\begin{array}{l}67.0 \\
81.7 \\
154 \\
97.1\end{array}$ & $\left|\begin{array}{c}127.0 \\
156 \\
\frac{246.1}{170.2}\end{array}\right|$ & $\begin{array}{r}45.2 \\
75.5 \\
116.1 \\
55.0\end{array}$ & $\left|\begin{array}{l}125.0 \\
182.1 \\
211.5 \\
156.3\end{array}\right|$ & $\begin{array}{l}32.0 \\
48.0 \\
45.8 \\
50.4\end{array}$ & $\left|\begin{array}{r}61.5 \\
79.3 \\
109.0 \\
96.2\end{array}\right|$ & $\left|\begin{array}{l}21.0 \\
30.8 \\
26.0 \\
34.6\end{array}\right|$ & $\begin{array}{l}36.0 \\
42.3 \\
50.5 \\
50.2\end{array}$ \\
\hline $\begin{array}{l}1.25 \\
\mathrm{mg}\end{array}$ & $\begin{array}{l}\mathrm{T} \cdot \text { 単独投与（対照） } \\
\mathrm{T}: \mathrm{E}=10: 1 \\
\mathrm{~T}: \mathrm{E}=20: 1 \\
\mathrm{~T}: \mathrm{E}=30: 1 \\
\mathrm{~T}: \mathrm{E}=40: 1\end{array}$ & & & & & $\left|\begin{array}{l}59.5 \\
27.1 \\
49.8 \\
51.9 \\
51.7\end{array}\right|$ & $\begin{array}{r}123.4 \\
63.0 \\
122.6 \\
146.8 \\
101.4\end{array}$ & $\begin{array}{r}61.2 \\
65.9 \\
159.1 \\
73.2 \\
85.3 \\
\end{array}$ & $\begin{array}{l}110.5 \\
134.2 \\
186.8 \\
150.5 \\
154.4\end{array}$ & $\begin{array}{r}\frac{43.0}{101.3} \\
\frac{163.5}{107.1} \\
72.0\end{array}$ & $\mid \begin{array}{l}110.2 \\
161.3 \\
227.2 \\
183.4 \\
144.5\end{array}$ & $\begin{array}{l}29.5 \\
49.0 \\
65.0 \\
62.5 \\
77.0\end{array}$ & $\begin{array}{r}48.0 \\
88.9 \\
127.0 \\
152.0 \\
101.9\end{array}$ & $\left|\begin{array}{l}18.3 \\
44.3 \\
80.9 \\
58.2 \\
59.6\end{array}\right| 1$ & $\begin{array}{r}34.0 \\
66.0 \\
122.3 \\
108.3 \\
87.2\end{array}$ \\
\hline
\end{tabular}

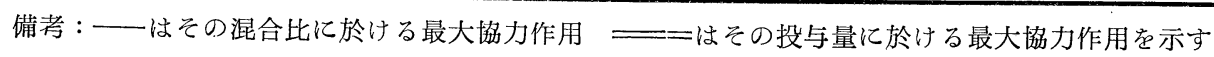

第 1 図 Androgen 及び Estrogen 混合剂1.25mg投与時の協力作用の比較 （去勢ラツテ精霊前立腺試験による）

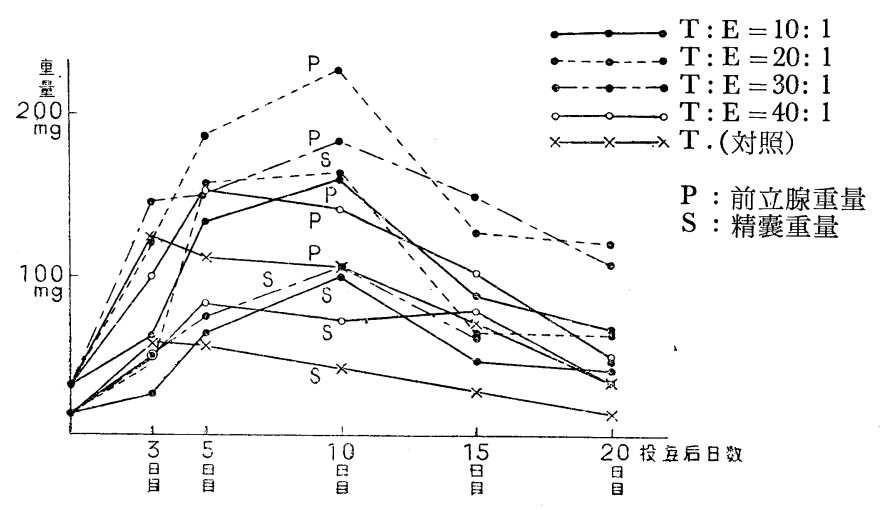

第34巻 第 6 号 
第 2 図 Androgen 及び Estrogen 混合剂 $2.5 \mathrm{mg}$ 投与時の協力作用の比較 （去勢ラッテ精襄前立腺試験による）

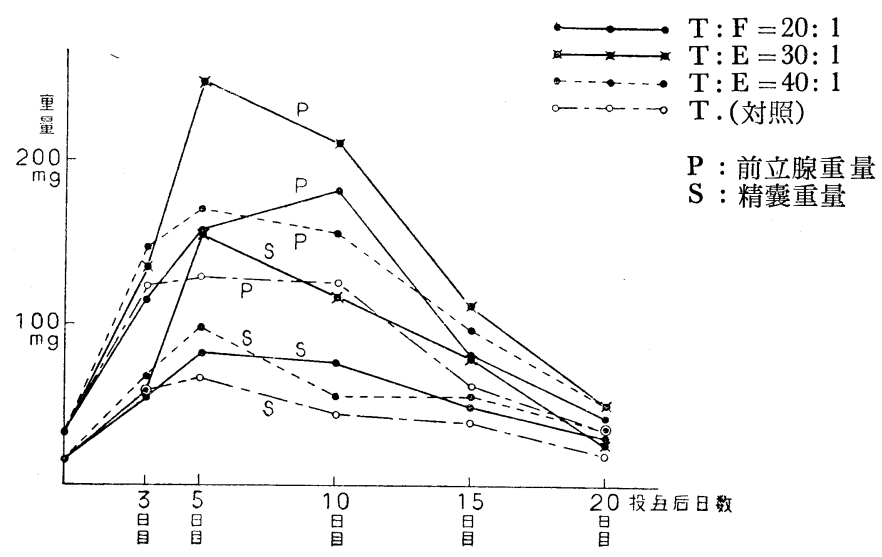

第 3 図 Androgen 及び Estrogen 混合剂 $5 \mathrm{mg}$ 投与時の協力作用る比較 （去勢ラツテ精閛前立腺試験による）

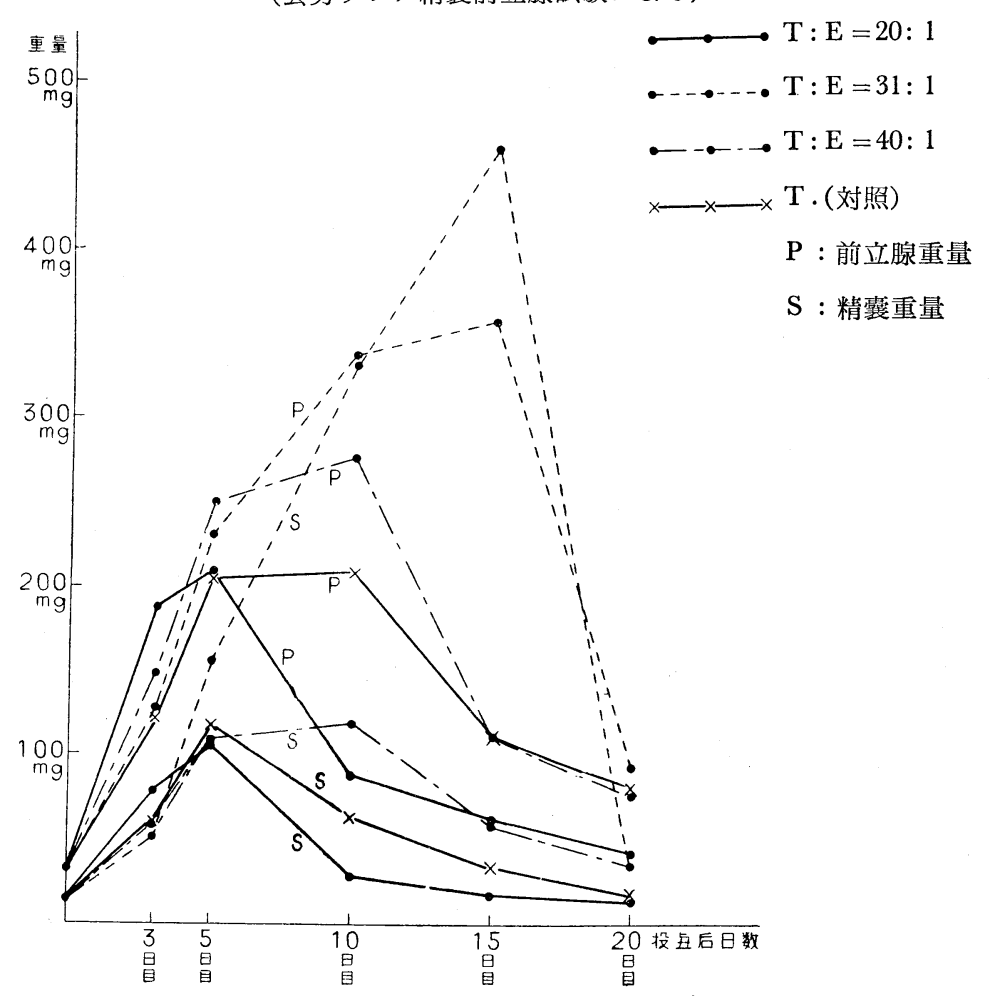


第 4 図 T.C.P. 及び混合ホルモンデポ剤各 $5 \mathrm{mg}$ 投与時の効力比較

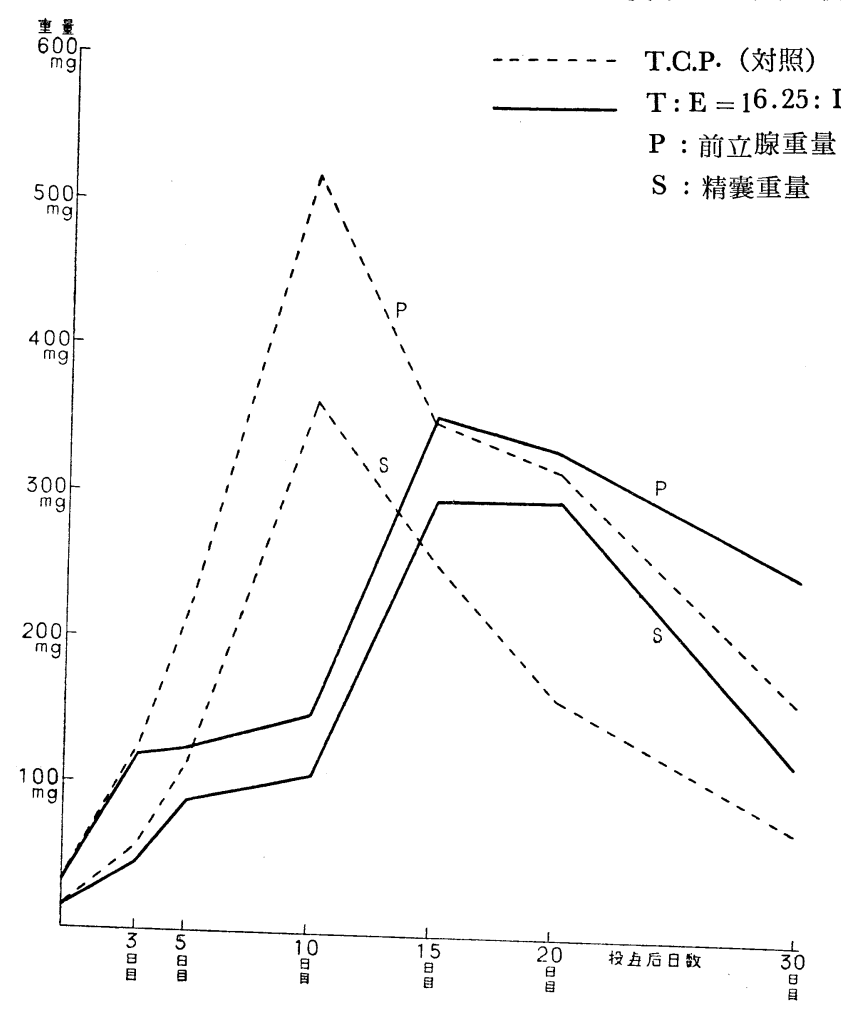

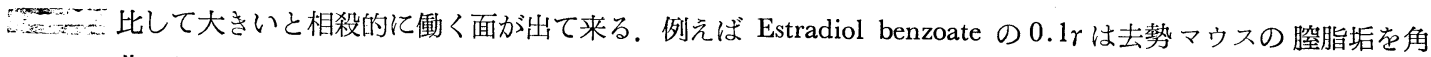

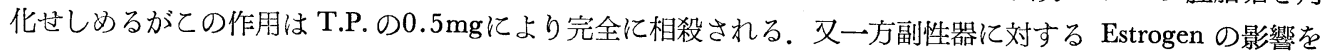
見るに Gesichikter5)によれば Estrogen の少量乃至中等量では副性器の 軙度な增大を，大量ではその縮少を 起す．即ち副性器に対する抑制効果を現わす Estrogen の最少有効量は連日注射で1 R.u.以上であると言う.

従つて混合ホルモンの協力作用を期待するには Androgen にでく少量の Estrogen を混合するととによつ て達せられるが，最大の協力作用を発揮する混合比を決定するに当つては色々と難しい問題が出て来る. 即 ち混合ホルモンの協力作用に影響を与える三要素として(1)同時に投与する Steroid hormone の混合比, (2)混 合ホルモンの投与量, (3)Target Organ の感受性がある. 更らにその協力作用は投与後の経過日数によつて あ色々に変化して来るので，その最大協力作用を発揮する混合比を決定するに当つては同一藏器の感受性を 基礎としてその投与量及び混合比を種々変化さすと共に投与後の経過日数を追つて観察しなければならない， ての混合比については前述の如く臨床的には多くの研究がなされている. 即ち Margolese $\left.{ }^{6}\right)$ は Estrogenの 副作用である出血を防止するには Testosterone Propionate $20 \mathrm{mg}$ Estradiol benzoate $1 \mathrm{mg}$ の混合比が良

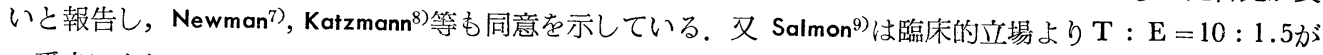
一番良いとしている。，その他臨床的にその治療上の効果より色々な混合比が報告されているが ${ }^{10-15}$ 動物実験 による協力作用の検討は割合に少ない. 安藤 ${ }^{16)}$ の去勢雄雞雞冠陚験に於いては投与量によりその混合比が或 いは50：1, 或いは20：1 亿最大の男性ホルモン作用を琹めているが私の去勢ラッテ精囊前立腺試験に於い ては $1.25 \mathrm{mg}, 2.5 \mathrm{mg}, 5 \mathrm{mg}$ 投与群に於いて何れも20:1或いは $30: 1$ 亿最大協力作用が認められた.

然し乍らとの協力作用について第 1 図, 第 2 図, 第 3 図及び第 4 図を詳細に検討するに Androgen に比し Estrogen の混合比の多いもの及び投与 Estrogen の絶対量の多いものに於いては Androgen 単独投与に比 


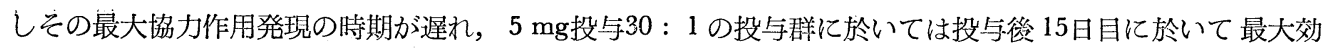
果を示し，その後急激に衰えている. 又同じく $5 \mathrm{mg}$ 投与 $20: 1$ の場合は T. $5 \mathrm{mg}$ 単独投与に比し最大効力 弱く，又効力持続時間屯短い. このととは $5 \mathrm{mg}$ 投与の混合ホルモンデポ剂に於いても T.C.P. $5 \mathrm{mg}$ 投与の場 合よりもその効力発現方衰えている. 即ち男性ホルモン作用の增強が認められなかつた。

以上のととは Estrogen の絶体量が多い程その Estrogen 本来の Androgen 亿対する拮抗作用が出て来る

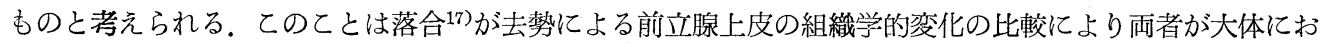
いて似ているてとから Estrogen の投与によつて前立腺の重量とか, 容積が増加するが，それは見掛上のも ので，前立腺に対する真の発育刺㦸というよりはむしろ Estrogen が前立腺上皮に発育抑制的に作用したも のと解すべきであろうと述へている様に，Androgen と Estrogen の協力作用の裏には常に Androgen に対 する Estrogen の拮抗作用が秘められていて Estrogen の投与量が增すにつれ微妙にそれが出て来るものと 考えられる. 又最大協力作用の発現の時期が遅れるてとについては，臸脂垢によつて Estrogen 少量投与時 の有効持続日数が 8 日迄であると言う綦実（安藤18)）から，同時に投与する Estrogen の量が多い場合は最 初はその Estrogen の Androgen に対する抑制作用により完全な男性ホルモン作用を発揮し得ず，Estrogen 作用の衰えて来た10日〜15日目に於いてはじめて完全なる最大男性ホルモン作用が発現したすのと推論し得 る.

\section{第 4 章 結論}

(1) “去勢ラッテ精囊前立腺試験によつて，Androgen 及び Estrogen 混合剂の各投与量，混合比及び投与 後の協力作用を逐日追及し，各投与量における最大協力作用を発揮する混合比及び投与衡日数を決定した.

（2）混合する Estrogen の量が多くなるに従つてその最大協力作用の発現の時期が遅れ，又充分な協力作 用を発揮し得なくなることを知つた。このととより混合ホルモン使用時に男性ホルモン作用增強を期待する ためには，Estrogen 量が大量になつてはならないととがわかつた。

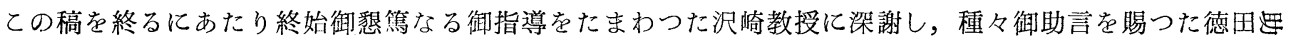
教授，種々製剂の提供を睗つた帝国臟器，三共，シエーリング各社に感謝いたします.

\section{文献}

1）志田：臨婦産，9，13，(昭30). $\quad 2 ）$ Korenchevsky：Brit. Med. J. 1:145, (1940).

Castillo, Dell., and Pinto：内分泌のつぞい第 4 集，P.47. 4 4) Korenchevaky：Ergebnisse der Vitamen u Hormonforsching 418, (1939).

5) Gesichickter : Die Prostata, Lei Pzig (1940).

6) Margolese : J. Clin. Endocrinol. $4: 394$, (1953). 7) Newman : Am. J. Obst. Gynec. $63: 607$, (1951). 8) Katzman : Am. J. Obst. Gynec. 63 : 1338, (1952). 19 9) Salmon, U.J.: Progressin Gynaecology, Grune and Stratton (1946)。 10) 足立: 治療, 35;302, (昭28).

11) 原田，芝原：産婦世界， 6;467，(昭29)。12）松本，鈴木：産婦の実際，3;161，(昭29). 13) 水野, 鈴本: 産と婦, 20; 725 ，（昭28）。14）長肉，渡辺：産婦世界，5;1038，（昭28）。 15) 安井他: 逓信医学, 6;787, (昭29)。 16) 安藤(晴)：産婦の世界，4;12，(昭27).

P 49. 18) 安藤: 産と婦, 22;1, (昭30).

17) 落合 : 内分泌のつどい，第 4 集, 